УДК 37.034

\title{
СОЦИАЛЬНО-ПЕДАГОГИЧЕСКИЙ ПОТЕНЦИАЛ СОВРЕМЕННОЙ СЕЛЬСКОЙ ШКОЛЫ
}

\author{
Камышанова Татьяна Геннадьевна \\ к.п.н., директор \\ МБОУ «Гимназия № 11 города Ельца»
}

\begin{abstract}
Аннотация: автор статьи раскрывает социально-педагогический потенциал современной сельской школы в условиях реализации национального проекта «Образование». Представлено влияние природы на уровень развития экологической культуры ребенка. Установлено, что каждая сельская школа обладает своей спецификой и уникальностью.
\end{abstract}

Ключевые слова: сельский учитель, сельская школа, цифровизация образования, индивидуализация обучения, уникальность

\section{SOCIO-PEDAGOGICAL POTENTIAL OF MODERN RURAL SCHOOL}

\section{Kamyshanova Tatiana Gennadievna}

\begin{abstract}
The article is devoted to socio-pedagogical potential of a modern rural school. The author shows the influence of nature on the level of the development of ecological culture of a child. It is defined that every rural school has its own specificity and uniqueness.

Key words: rural teacher, rural school, digitalization of education, individualization of education, uniqueness.

Снова перечитала статью о сельской школе. Впечатлил последний абзац, журналист спрашивал детей, чем займетесь после прощания со школой. «После школы, конечно, уедем отсюда!» - отвечает один из мальчиков, и его дружно поддерживают одноклассники. «Поедем в город, продолжим учиться» - говорит Президент школьной республики «Маленькая страна» [1].

Ученики земской школы в середине XIX века и на рубеже XX даже подумать не могли о продолжении обучения в городе, в университете. Деревню покидали для продолжения образования лишь единицы, которым
\end{abstract}


посчастливилось найти покровителей: помещиков, купцов, оценивших детскую даровитость. Н.А. Некрасов так описал эту ситуацию:

«...Не без добрых душ на свете -

Кто-нибудь свезет в Москву,

Будешь в университете -

Сон свершится наяву!» [2]

Земская школа никогда не ориентировала учеников к продолжению образования, а их на территории России было немало. Например, в Липецкой области школа села Черепянь Лебедянского района недавно отпраздновала свое 140-летие, как и школа села Кузовлевка Лев-Толстовского района. В царское время школа села Кузовлевка даже не имела собственного здания, занятия проходили в сторожке для паломников. Требования к учителю были минимальные: научить грамоте и счету. Ребенку с таким багажом знаний не суждено было стать инженером, врачом, офицером. Считалось, основным предназначением детей крестьянина является неквалифицированный труд ради благополучия помещика. Крестьянину мог только «ломать» шапку перед начальством и исполнять чужую волю.

В середине XIX века Л.Н. Толстой, увлекшись вопросами образования, совершая первое заграничное путешествие по странам Европы (Франция, Италия, Германия), задумался об открытии в Ясной Поляне бесплатной школы для крестьянских детей (в земских школах за обучение детей крестьяне платили). Школа открылась во флигеле усадьбы графа Л.Н. Толстого. Копировать существующую в то время казенную педагогику Лев Николаевич не стал, создал свою педагогическую систему, которая вошла в историю педагогики под названием «Школа свободного воспитания» [3]. В своих программных статьях, опубликованных в журналах: «Ясная поляна», «О народном образовании», «Прогресс и определение образования», «Дневник Яснополянской школы», «Воспитание и образование», Л.Н. Толстой раскрывает изъяны обучения в земской школе: механическое, бессмысленное заучивание текстов учебников, слепое копирование методик из арсенала немецкой педагогики, базирующейся на постулатах И. Канта о гносеологическом субъекте. Такая педагогика, отмечал Л.Н. Толстой, не развивает ум, нравственные качества ребенка. Лев Николаевич писал: «В школах вы видите измученное, сжавшееся существо, с выражением усталости, страха и скуки, повторяющее одними губами чужие слова на чужом языке... Все высшие способности: воображение, творчество, 
соображение уступают место каким-то другим - произносить звуки, считать числа сряду: 1, 2, 3, 4, 5, воспринимать слова, не допуская воображению подставлять под них какие-нибудь образы» [4, стр. 14].

Художник Михаил Нестеров изобразил такое «сжавшееся существо» в своей картине «Экзамен в сельской школе» (1884). Взъерошенный ученик стоит перед экзаменационной комиссией, прячет за спиной учебник, чешет затылок. Его фигура напоминает вопросительный знак, который эхом отзывается на фигуре учителя. Учитель старается: задает вопросы. Но, увы, методика Корфа - кредо земских учителей - не срабатывает, а наоборот, уводит ребенка от понимания сущности изучаемого предмета, явления.

Конечно, и в то время были педагоги-новаторы. На картине Н.П. Богданова-Бельского «Устный счет. В народной школе С.А. Рачинского» (1895), мы видим ребят столпившихся у доски, на которой записан очень сложный пример; представлена живая дискуссия детей, с большим интересом изучающих арифметику.

К.Д. Ушинский считал, что именно сельская школа должна и может стать локомотивом развития образования в России, придать ему смысл и содержание.

В 20-30-е годы XX века земская школа, как институт исчезла, она стала частью государственной системы образования, с единообразием учебных программ, методик и управления. Н.К. Крупская, с 1929 года - заместитель наркома просвещения РСФСР, настаивала на модели политехнической школы, независимо от того, где находится школа - в городе или в селе.

Но в 90-е годы XX века сельская школа оказалась на обочине российского образования: молодые учителя, из-за падения престижа профессии, отказывались работать в сельской школе, материально-техническая база сельских школ безнадежно устаревала, число учащихся сокращалось - школы становились малокомплектными.

И только за последние 20 лет (от введения Комплекса мер по модернизации системы общего в Российского образования до Национального проекта «Образование») сельская школа совершила инновационный рывок в развитии образования. Сегодня цифровизация образования в сельской школе позволяет эффективно применять дистанционное, электронное обучение учеников и учителей: ученики сельской школы могут получать консультации ведущих учителей России, быть участниками международных, Всероссийских конференций, участниками Всероссийских проектов, например, таких как 
«ПроеКТОриЯ». Ученики с ограниченными возможностями здоровья, дети-инвалиды получили возможность обучаться со своими сверстниками в Центрах «Точка роста». Учителя, используя возможности дистанционного обучения, овладевают актуальными образовательными технологиями, овладевают новыми профессиональными компетенциями, принимают участие в конкурсах профессионального мастерства, вебинарах, Всероссийских культурно-образовательных проектах, например, «Сельский учитель в большой России».

Как оказалось, педагогические новации легче «приживаются» в сельской школе по причине гомогенности жизненной среды - сельского социума. Учитель на селе - непререкаемый авторитет, который может в полной мере использовать педагогические ресурсы семьи, общественное мнение сельского социума. Как правило, учитель в сельской школе преподает сразу несколько дисциплин, ему необходимо постоянно учиться, осваивать новые знания, применять новые достижения педагогической науки на практике. Небольшое количество обучающихся в классе, по сравнению с городскими школами, позволяет в полной мере сельскому учителю реализовать принцип индивидуализации обучения, применять системнодеятельностный подход на уроках, в соответствии с требованиями новых Федеральных государственных образовательных стандартов. В силу менталитета сельчан межличностные отношения носят личностный, а не формализованный характер. Поэтому не вызывает удивления наличие в школе села Лесниково Гусь-Хрустального района Владимирской области (школа трижды становилась лучшей сельской школой в России, была лауреатом III международного конкурса им. А.С. Макаренко, победителем Всероссийского конкурса «За нравственный подвиг учителя», лауреатом Всероссийского конкурса «Образовательная организация XXI века. Лига лидеров-2020) школьной республики «Маленькая страна». Это, конечно, игровая, вместе с тем, интересная инновационная модель в области социального и гражданского воспитания, нацеленная на формирование подлинного участника постиндустриальных модернизаций. В «Маленькой стране» есть своя Конституция, Гимн, паспорт, банковская и торговая система, СМИ, нормативные акты, регулирующие жизнь граждан этой маленькой страны. Каждые два года в школьной республике проходят выборы Президента из обучающихся, им предшествуют мини дебаты и интеллектуальные сражения, обсуждения программ кандидатов. 
И еще, в отличие от городской, есть в сельской школе один великий наставник - Природа. Горожане утрачивают способность «видеть» природу - её отодвинул мегаполис, антиэкологичный по своему содержанию, с громадой каменных зданий и линейками магистралей, с подстриженными в парках деревьями и геометрической сеткой аллей, которые по замыслу ландшафных дизайнеров, должны восприниматься как произведения искусства, являть собой либо театральное зрелище (итальянские сады), либо ясность и геометрию простых форм: кубов, конусов, цилиндров (Версаль с подстриженными деревьями). Но произведение искусства предполагает дистанцию для созерцания, к нему трудно относится как к живому существу. Сельские дети умеют слушать и слышат природу: шелест листьев, треск кузнечиков, песню иволги. Возникает, говоря слова А.А. Ухтомского, «любовная связь с природой, общая жизнь с нею, любовная ответственность за природу».

Таким образом, в селе само окружение - предпосылка для формирования экологической культуры личности. Конечно, экологическая культура не появляется просто так, на пустом месте. Необходима работа учителя, который вместе со своими учениками найдет ответы на многие вопросы: «Каково значение птицы кедровки в восстановлении кедровых лесов? Почему каждую птицу можно охарактеризовать как настоящий летающий зоопарк? Под пологом березы поселился еловый подрост. Какова судьба будущего леса?»

Какое будущее ожидает сельскую школу? Прежде всего, сельская школа - это школа обучения детей работе на своей земле, а значит, творческая лаборатория для апробации методик экологического воспитания, новых педагогических здоровьесберегающих технологий, технологий личностно-ориентированного обучения и воспитания.

Главное, чтобы сельская школа не потеряла свою специфику и уникальность. Часто в рекламных роликах показывают строящиеся в селах небоскребы. Как бы не стали строить в них школы городского типа. Массовость всегда рождает стандартизацию, уничтожая уникальность. 


\section{Список литературы}

1. https://www.kommersant.ru/doc/3508571.

2. Некрасов Н.А., [Текст] // «Школьник» - 1856. -С. 235.

3. Толстой Л.Н. «Школа свободного воспитания» [Текст] // Педагогическое наследие Л.Н. Толстого. - 1975 - С. 465 . Полн. собр. сочинений, т. 8,стр. 33.

4. Толстой Л.Н. О свободе возникновения и развитии школ в народе. [Текст] // Педагогическое наследие Л.Н. Толстого. - 1975 - С. 465 . Полн. собр. сочинений, т. 8,стр. 403.

5. Толстой Л.Н. О народном образовании [Текст] // Педагогическое наследие Л.Н. Толстого. - 1975 - С. 465 . Полн. собр. сочинений, т. 8,стр. 450. 